\title{
Effects of Norepinephrine and Acetylcholine on the Development of Cultured Leydig Cells in Mice
}

\author{
Shuying Huo, Xiuhui Zhong, Xianjun Wu, and Yurong Li \\ College of Animal Science \& Technology, Agricultural University of Hebei, Baoding 071001, China \\ Correspondence should be addressed to Shuying Huo, huoshuying@163.com
}

Received 8 April 2012; Revised 27 May 2012; Accepted 18 June 2012

Academic Editor: Stelvio M. Bandiera

Copyright ( $) 2012$ Shuying Huo et al. This is an open access article distributed under the Creative Commons Attribution License, which permits unrestricted use, distribution, and reproduction in any medium, provided the original work is properly cited.

\begin{abstract}
Few data have suggested how norepinephrine (NE) and acetylcholine (Ach) regulate the development of Leydig cells in mice at prepuberty, except for data indicating endocrine effects. The present study aims to elucidate the roles of NE and Ach on the differentiation and proliferation of Leydig cells. Firstly, the expression of adrenergic receptors and muscarinic acetylcholine receptors in Leydig cells was investigated. It was found that adrenergic receptors $(\beta 1 \mathrm{AR}, \beta 2 \mathrm{AR}$, and $\alpha 1 \mathrm{D})$ and muscarinic acetylcholine receptors (M1 and M3) mRNA are expressed in adult Leydig cells. Then, the effects of NE and Ach on the differentiation and proliferation of Leydig cells were analyzed. The results showed that NE and Ach at $10 \mu \mathrm{M}$ significantly increased the number of $3 \beta$ hydroxysteroid-dehydrogenase- (3 $\beta$-HSD-) positive Leydig cells and improved the expression of proliferating cell nuclear antigen (PCNA) in Leydig cells on postnatal day (PD) $15(P<0.05)$. NE and Ach at $10 \mu \mathrm{M}$ had no impact on the expression of PCNA mRNA $(P>0.05)$, but reduced the expression of $3 \beta$-HSD mRNA in adult Leydig cells and a murine Leydig tumor cell line (MLTC1) $(P<0.05)$. Therefore, a conclusion may be reached that NE and Ach participated in stimulating the development of Leydig cells in mice from prepuberty to adult stage.
\end{abstract}

\section{Introduction}

It has been generally acknowledged that Leydig cells play a key role in synthesizing testosterone and regulating the spermatogenesis. The final population of Leydig cells in the adult testis is established depending on the proliferation and differentiation of Leydig cells at prepuberty and develops to the adult population of Leydig cells $[1,2]$. The adult Leydig cells develop from stem Leydig cells through several steps of differentiation and proliferation which occur during prepuberty [3]. Compared with the endocrine effects, previous data seldom demonstrate the effects of norepinephrine (NE) and acetylcholine (Ach) on the development of Leydig cells through their receptors.

$\alpha$-Adrenergic and $\beta$-adrenergic receptors may be subclassified into three receptors, that is, $\alpha 1 \mathrm{~A}, \alpha 1 \mathrm{~B}, \alpha 1 \mathrm{D}$, and $\beta 1 \mathrm{AR}, \beta 2 \mathrm{AR}, \beta 3 \mathrm{AR}$, respectively. $\beta 2 \mathrm{AR}$ is more widely expressed [4-6]. Muscarinic acetylcholine receptors (mAChRs) include five subtypes, that is, M1, M2, M3, M4, and M5 [7]. As of yet, the expression of adrenergic and muscarinic acetylcholine receptors in testicular Leydig cells has been unclear. It was indicated in some studies that catecholamine was capable of stimulating the secretion of testosterone through both alpha- and beta-adrenergic receptors in the immature testis of the golden hamster [8]. Moreover, carbachol, a cholinergic agonist, is capable of inhibiting the secretion of testosterone via purified rat Leydig cells $[9,10]$.

One objective of the present study is to elucidate the expression of adrenergic and muscarinic acetylcholine receptors in the testicular Leydig cells of mice. Another objective is to investigate the effects of $\mathrm{NE}$ and Ach on the proliferation and differentiation of Leydig cells at prepuberty.

\section{Material and Methods}

2.1. Animals. Male Kunming mice (Peking University Health Science Center) aged PD (postnatal days) 15 and 50 were used in this study. Mice were kept in cages with a $12 / 12 \mathrm{~h}$ light/dark cycle at the controlled temperature of $23 \pm 2^{\circ} \mathrm{C}$, with water and food provided ad libitum. All experimental 
animals and designs used to achieve the purposes of this study were approved by the Chinese Association for Laboratory Animal Sciences.

2.2. Isolation and Purification of Primary Leydig Cells. The testes of mice aged PD 15 and PD 50 were removed and placed in the prechilled 1:1 mixture of Ham's F12 medium and DMEM, then transferred to ice, with the procedure performed as previously described [16]. The testes were then decapsulated and mechanically dispersed in the medium and subjected to enzymatic digestion in the shaking water bath, using $5 \mathrm{mg}$ collagenase (type IV, $213 \mathrm{U} / \mathrm{mg}$; Worthington Biochemical Corp., Freehold, NJ, USA) in $20 \mathrm{~mL}$ Ham F12/DMEM $(1: 1)$, at $34^{\circ} \mathrm{C}$ for $30 \mathrm{~min}$. Following this digestion procedure, the collagenase solution was diluted four times with a culture medium, then filtered through a stainless-steel mesh to separate tissue fragments. The cells were then collected via centrifugation $(1,500 \mathrm{r} / \mathrm{min}$ for $10 \mathrm{~min})$ and resuspended in $2 \mathrm{~mL}$ of the culture medium mentioned above. The Leydig cells were purified discontinuously with a four-layer Percoll density gradient $(21 \%, 26 \%, 37 \%$, and $60 \%$ ). The gradient was centrifuged at $3,000 \mathrm{r} / \mathrm{min}$ for $30 \mathrm{~min}$ at $4^{\circ} \mathrm{C}$. The interface between $37 \%$ and $60 \%$ was collected and washed with the medium to remove Percoll. The cells isolated from the PD 15 mice were progenitor cells and immature Leydig cells. The cells isolated from the PD 50 mice were adult Leydig cells, and the purity of the Leydig cells examined by histochemical staining for $3 \beta$-HSD using $1 \mathrm{mg} / \mathrm{mL}$ etiocholanolone as the enzyme substrate was observed to be $85 \%$. Some of the purified Leydig cells were used for detecting the expression of adrenergic and muscarinic acetylcholine receptors, and others for Leydig cell culture.

2.3. Cell Culture and Treatment. The purified Leydig cells were placed in 24 -well $\left(1 \times 10^{5}\right.$ cells $/ \mathrm{mL} /$ well $)$ plates with Ham's F12/DMEM culture medium supplemented with $10 \%$ charcoal-stripped fetal bovine serum and antibiotics. Culture was performed at $34^{\circ} \mathrm{C}$ in a controlled humidified atmosphere with $5 \% \mathrm{CO}_{2}$ in the air supply. After remaining for $24 \mathrm{~h}$ in the culture, the cells were washed twice with a serum-free medium, and then treated with different doses of NE $(0.1 \mu \mathrm{M}, 1 \mu \mathrm{M}, 10 \mu \mathrm{M}$, and $100 \mu \mathrm{M})$ and Ach $(0.1 \mu \mathrm{M}$, $1 \mu \mathrm{M}, 10 \mu \mathrm{M}$, and $100 \mu \mathrm{M})$ for $24 \mathrm{~h}$. After the incubation, the Leydig cells were collected from the 24 -well plates.

2.4. MTT Cell Viability Assay. After the cells were treated with different doses of NE and Ach for $24 \mathrm{~h}$, the culture medium was filtered out and the cells were harvested, re-suspended in $200 \mu \mathrm{L}$ 3-(4, 5-dimethylthiazol-2yl)-2, 5diphenyltetrazolium bromide (MTT) working solution ( $5 \mathrm{mg} / \mathrm{mL}$ methylthiazolyldiphenyl-tetrazolium bromide in PBS), then incubated for $2 \mathrm{~h}$ at $37^{\circ} \mathrm{C}$. The converted dye was solubilized with $3 \mathrm{~mL}$ acidic isopropanol $(0.04 \mathrm{M} \mathrm{HCl}$ in absolute isopropanol), the absorbance of which was measured at a wavelength of $570 \mathrm{~nm}$ with a background subtraction at $650 \mathrm{~nm}$ [17].
2.5. Total RNA Extraction and Semiquantitative RT-PCR. Total RNA was extracted from the adult Leydig cells and prepuberty Leydig cells using Trizol (Invitrogen, Carlsbad, CA, USA). Two micrograms of total RNA were reversely transcribed using $200 \mathrm{U}$ of Superscript II Rnase H-Reverse Transcriptase (Gibco BRL, Bethesda, MD, USA) in a $25 \mu \mathrm{L}$ reaction volume in the presence of $10 \mu \mathrm{M}$ Oligo (dT), first strand buffer $(50 \mathrm{mM}$ Tris- $\mathrm{HCl}, 75 \mathrm{mM} \mathrm{KCl}$, and $3 \mathrm{mM}$ $\mathrm{MgCl}_{2}$ ), $0.01 \mathrm{M}$ dithiothreitol, and $10 \mathrm{mM}$ of each dATP, dGTP, dCTP and dTTP. The mixture of RNA and Oligo dT was heated at $65^{\circ} \mathrm{C}$ for $5 \mathrm{~min}$, then cooled to $4^{\circ} \mathrm{C}$. The other reagents were added and $\mathrm{RT}$ was performed at $42^{\circ} \mathrm{C}$ for $1 \mathrm{~h}$.

PCR amplification of adrenergic receptors $(\beta 1 \mathrm{AR}, \beta 2 \mathrm{AR}$, $\beta 3 \mathrm{AR}, \alpha 1 \mathrm{~A}, \alpha 1 \mathrm{~B}$, and $\alpha 1 \mathrm{D})$ and acetylcholine receptors (M1, M2, M3, M4, and M5), 3 $\beta$-HSD, PCNA, and GAPDH (a housekeeping gene) was carried out using primer pairs from published sources (Table 1). The size of the PCR products was determined through comparison with a gene marker (100 bp DNA, Promega, Madison, WI, USA) run in parallel with RT-PCR products in 1.2\% agarose gel containing ethidium bromide. The relative band intensity was quantified using a computer-assisted image analysis system (Visage 2000, BioImage, Ann Arbor, MI, USA). The integrated optical density (IOD) values for $3 \beta$-HSD, PCNA, and GAPDH in each band were normalized with the corresponding GAPDH expressions.

2.6. Immunohistochemistry. Leydig cells isolated from the PD 15 mice were cultured on glass coverslips in the presence of $10 \mu \mathrm{M}$ NE and Ach in 24-well plates. After remaining for $24 \mathrm{~h}$ in the culture, the medium was removed, the coverslips were rinsed with phosphate-buffered saline (PBS, $0.01 \mathrm{M}, \mathrm{pH}$ 7.4) and fixed in 4\% paraformaldehyde in PBS for $20 \mathrm{~min}$ at room temperature, followed by penetration with $0.2 \%$ Triton X-100 in PBS for $15 \mathrm{~min}$. Subsequently, the differentiation and proliferation of the Leydig cells were assessed through detecting the expression of $3 \beta-\mathrm{HSD}$ and PCNA via immunohistochemistry and immunofluorescence. Endogenous peroxidase activity was blocked with 3\% hydrogen peroxide $\left(\mathrm{H}_{2} \mathrm{O}_{2}\right)$ in PBS for $30 \mathrm{~min}$ at room temperature. The coverslips were then rinsed in PBS and blocked with $10 \%$ normal donkey serum and goat serum, respectively, and incubated, respectively, with the two first antibodies, that is, mouse anti-3 $\beta$-HSD polyclonal antibody (diluted $1: 300$ in PBS/BSA-c) and PCNA monoclonal antibody (diluted $1: 2000$ in PBS/BSA-C), overnight at $4^{\circ} \mathrm{C}$. The coverslips were rinsed and incubated with secondary antibodies, biotinylated donkey anti-mouse, and goat anti-mouse IGg (diluted 1: 150 in PBS; Zymed, San Francisco, CA, USA) for $3 \mathrm{~h}$ at room temperature. The coverslips used for detecting the expression of $3 \beta$-HSD were washed in PBS and incubated with streptavidin-labeled peroxidase complex (diluted $1: 150$ in PBS; Zymed) for $3 \mathrm{~h}$ at room temperature; next, the antibody

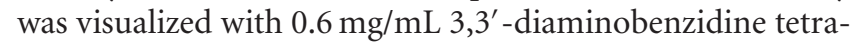
chloride (DAB, Sigma-Aldrich) dissolved in PBS, to which $0.03 \% \mathrm{H}_{2} \mathrm{O}_{2}$ was added (for brown staining); afterwards, the Leydig cells were counterstained, blued, and sealed with glycerine. The coverslips used for detecting the expression 
TABle 1: Primer sequences.

\begin{tabular}{|c|c|c|c|c|}
\hline & Primer sequence & Product size (bp) & Annealing temp. $\left({ }^{\circ} \mathrm{C}\right)$ & Reference \\
\hline \multirow{2}{*}{$\beta 1 \mathrm{AR}$} & F: CCGCTGCTACCACGACCCCAAG & \multirow{2}{*}{441} & \multirow{2}{*}{60} & \multirow{2}{*}[11]{} \\
\hline & R: AGCCAGTTGAAGAAGAGCAAGAGGCG & & & \\
\hline \multirow{2}{*}{$\beta 2 \mathrm{AR}$} & F: GGTTATCGTCCTGGCCATCGTGTTTG & \multirow{2}{*}{468} & \multirow{2}{*}{61} & \multirow{2}{*}{ v.s. } \\
\hline & R: TGGTTCGTGAAGAAGTCACAGCAAGTCTC & & & \\
\hline \multirow{2}{*}{$\beta 3 \mathrm{AR}$} & F: TCTAGTTCCCAGCGGAGTTTTCATCG & \multirow{2}{*}{337} & \multirow{2}{*}{64} & \multirow{2}{*}{ v.s. } \\
\hline & R: CGCGCACCTTCATAGCCATCAAACC & & & \\
\hline \multirow{2}{*}{$\alpha 1 \mathrm{~A}$} & F: GGACAAGTCAGACTCAGAGCAAGTGACG & \multirow{2}{*}{404} & \multirow{2}{*}{61} & \multirow{2}{*}{ v.s. } \\
\hline & R: TATAGCCCAGGGCATGCTTGGAAGAC & & & \\
\hline \multirow{2}{*}{$\alpha 1 \mathrm{~B}$} & F: TTTCATGAGGACACCCTCAGCAGTACC & \multirow{2}{*}{452} & \multirow{2}{*}{61} & \multirow{2}{*}{ v.s. } \\
\hline & R: CTGCCGCTGTCATCCAGAGAGTCC & & & \\
\hline \multirow{2}{*}{$\alpha 1 \mathrm{D}$} & F: CGCCAAAGGAAATCCAGGGACAC & \multirow{2}{*}{617} & \multirow{2}{*}{61} & \multirow{2}{*}{ v.s. } \\
\hline & R: CAGAGCGGAACTTATGGGACAGG & & & \\
\hline \multirow{2}{*}{ M1 } & F: GTAAGGTGCCTGCCATCCAATC & \multirow{2}{*}{417} & \multirow{2}{*}{58} & \multirow{2}{*}[12]{} \\
\hline & R: CGCAGCTCACTTTCTGCATTGT & & & \\
\hline \multirow{2}{*}{ M2 } & F: TGTCAGCAATGCCTCCGTTATG & \multirow{2}{*}{480} & \multirow{2}{*}{58} & \multirow{2}{*}{ v.s. } \\
\hline & R: GCCTTGCCATTCTGGATCTTG & & & \\
\hline M3 & F: GGTGTGATGATTGGTCTGGCTTG & 497 & 62 & v.s. \\
\hline & R: GAAGCAGAGTTTTCCAGGGAG & & & . \\
\hline M4 & F: TCAAGAGCCCTCTGATGAAGCC & 477 & 62 & v.s. \\
\hline & R: AGATTGTCCGAGTCACTTTGCG & & & \\
\hline M5 & F: GCTGACCTCCAAGGTTCCGATTC & 485 & 54 & v.s. \\
\hline & R: CCGTCAGCTTTTACCACCAAT & & & \\
\hline $3 \beta-H S D$ & F: ACTGCAGGAGGTCAGAGCT & 565 & 55 & [13] \\
\hline & R: GCCAGTAACACACAGAATACC & & & \\
\hline PCNA & F: TGGAATCCCAGAACAGG & 287 & 55 & {$[14]$} \\
\hline & R: ACAGTGGAGTGGCTTTT & & & \\
\hline GAPDH & F: AAACCCATCACCATCTTCCAG & 361 & 54 & [15] \\
\hline & R: AGGGGCCATCCACAGTCTTCT & & & \\
\hline
\end{tabular}

F: forward; R: reverse.

of PCNA were incubated with 1:50 dilution of fluorescein isothiocyanate (FITC)-conjugated streptavidin (Southern Biotech, Birmingham, AL, USA) for $3 \mathrm{~h}$ without exposure to light. After rinsing, the coverslips were stained with 1:50 dilution of Hoechst 33258 without exposure to light for $40 \mathrm{~min}$. After being rinsed in PBS for the final time, the slides were mounted with $75 \%$ glycerol in PBS. A Xuorescence microscope (Leica LB30T, Germany) equipped with a filter for FITC (Leica, I3-513808) was used for observation. Images were captured using a digital camera (Leica DFC320).

2.7. Statistical Analysis. Every step of the treatment in the same experiment and the specific experiment was repeated at least three times. All data were represented as means \pm SE. Statistical significance was tested using the Student's $t$ test. Differences between groups were considered significant if $P<0.05$.

\section{Results}

3.1. The Expression of Adrenergic and Muscarinic Acetylcholine Receptors mRNA in Leydig Cells of Adult Mouse Testis. RTPCR results showed that $\beta 1 \mathrm{AR}, \beta 2 \mathrm{AR}$, and $\alpha 1 \mathrm{D}$ receptors

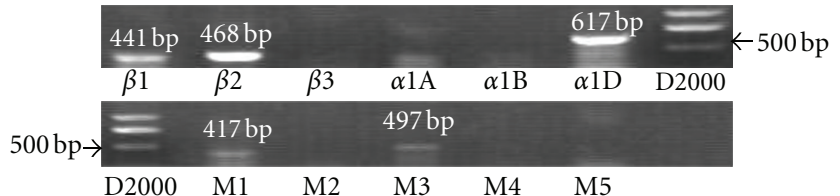

FIgURE 1: Expression of $\beta 1 \mathrm{AR}, \beta 2 \mathrm{AR}, \beta 3 \mathrm{AR}, \alpha 1 \mathrm{~A}, \alpha 1 \mathrm{~B}$, and $\alpha 1 \mathrm{D}$ receptors and M1, M2, M3, M4, and M5 receptors mRNA in Leydig cells of adult mouse testis. $\beta 1 \mathrm{AR}, \beta 2 \mathrm{AR}, \alpha 1 \mathrm{D}, \mathrm{M} 1$, and $\mathrm{M} 3$ receptors. PCR products of $441 \mathrm{bp}, 468 \mathrm{bp}, 617 \mathrm{bp}, 417 \mathrm{bp}$, and $497 \mathrm{bp}$ visualized by ethidium bromide staining are shown. D2000, size marker.

mRNA were expressed in adult Leydig cells, especially the $\beta 2 \mathrm{AR}$ and $\alpha 1 \mathrm{D}$ receptor mRNA (Figure 1). $\beta 3 \mathrm{AR}$ and $\alpha 1 \mathrm{~A}$ receptors mRNA were not detected in the adult Leydig cells. M1 and M3 receptors mRNA were expressed in adult Leydig cells, while M2, M4, and M5 receptors mRNA were not detected (Figure 1). The data indicated that NE and Ach stimulated the development of Leydig cells through some of the receptors, that is, $\beta 1 \mathrm{AR}, \beta 2 \mathrm{AR}, \alpha 1 \mathrm{D}$, or M1 and M3.

3.2. Effects of Different Doses of NE and Ach on the Viability of Mouse Leydig Cells in PD 15 Mice. The respective viabilities 


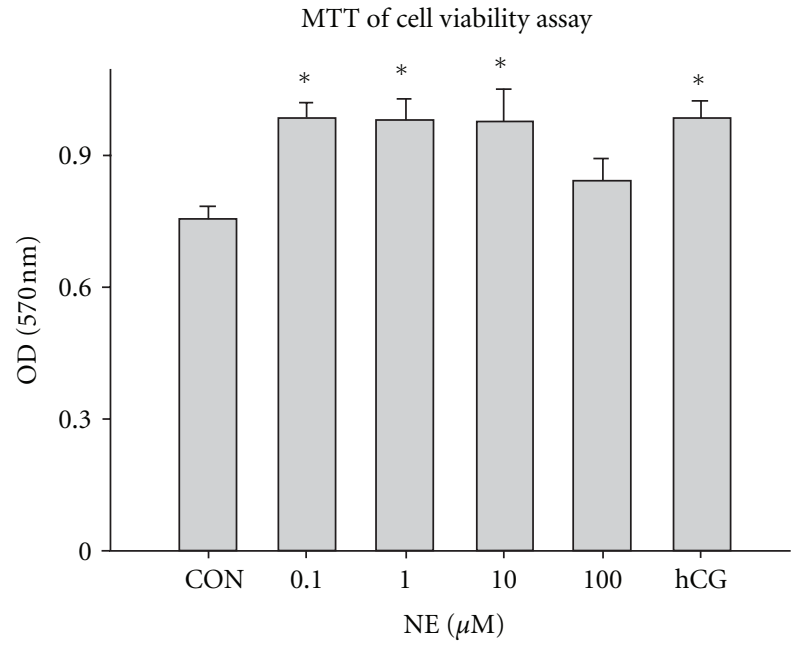

(a)

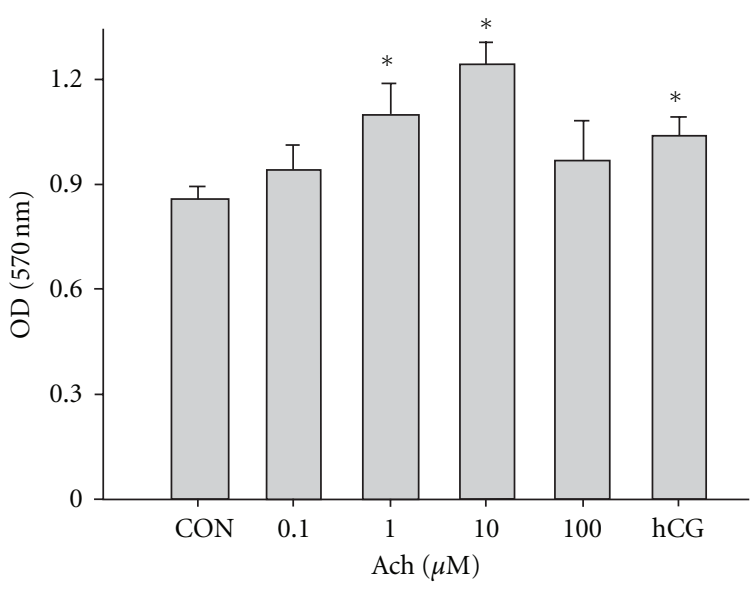

(b)

Figure 2: NE and Ach at doses of $0.1,1,10$, and $100 \mu \mathrm{M}$ on the viability of Leydig cells from mice on PD15. The viability of Leydig cells incubated with different doses of NE and Ach for $24 \mathrm{~h}$ was assessed using MTT assays. The data were presented as means \pm SEM. A single asterisks $(*)$ indicates statistical significance $(P<0.05)$ relative to the untreated control. CON: control group cultured with the same dilution of NE and Ach. hCG: hCG group cultured with hCG at the dose of $1 \mathrm{IU} / \mathrm{mL}$.
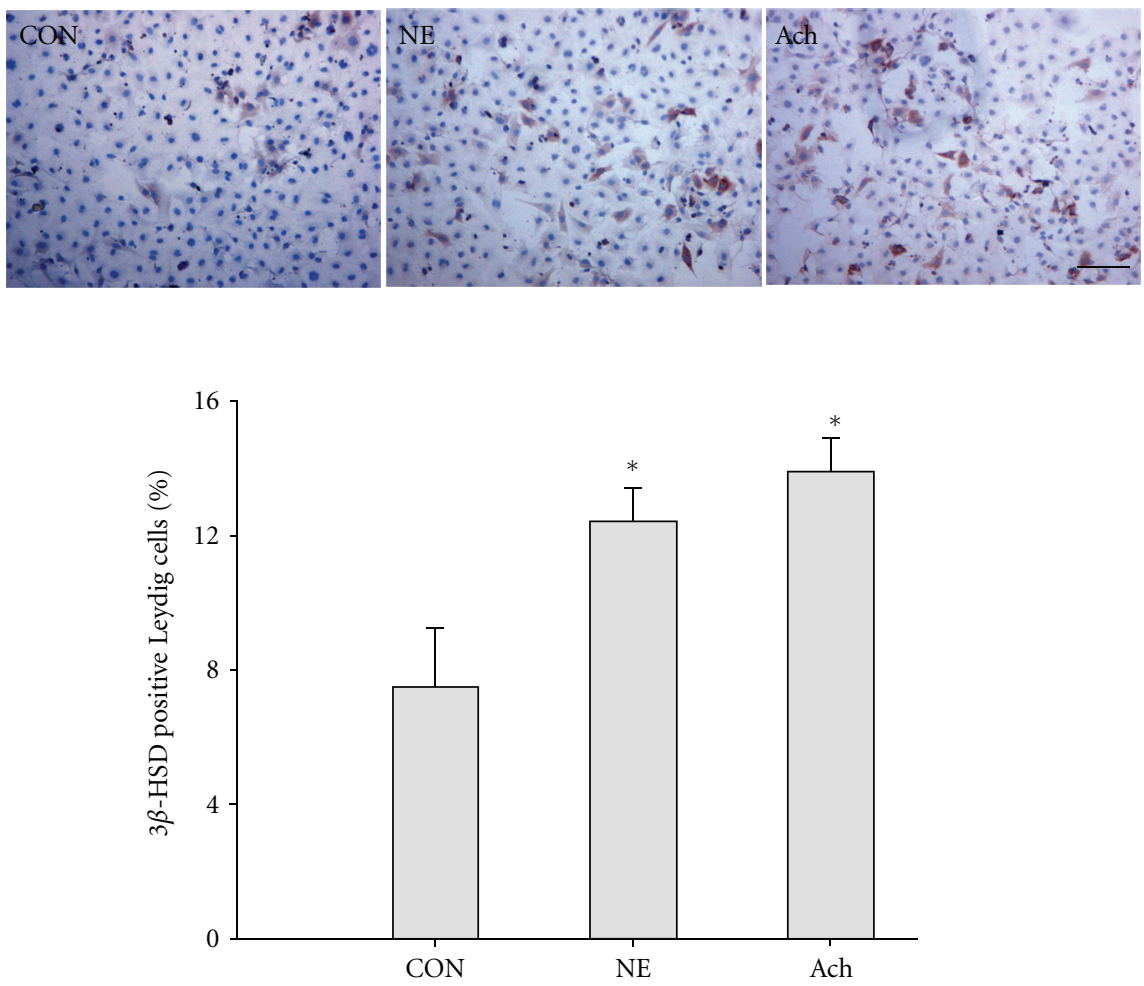

FIGURE 3: NE and Ach on the differentiation of precursor Leydig cells into $3 \beta$-HSD-positive Leydig cells. The percentage of 3 $\beta$-HSD-positive cells to total Leydig cells was determined and presented as means \pm SEM. A single asterisks $\left(^{*}\right)$ indicates statistical significance $(P<0.05)$ relative to the untreated control. CON: control group cultured with the same dilution of NE and Ach. NE: NE group cultured in the presence of $10 \mu \mathrm{M}$ NE. Ach: Ach group cultured in the presence of $10 \mu \mathrm{M}$ Ach. Bar $=50 \mu \mathrm{m}$. 


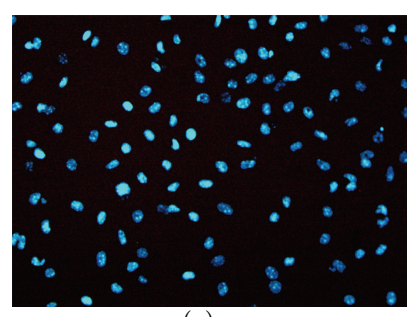

(a)

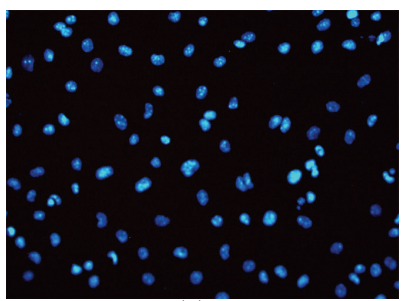

(c)

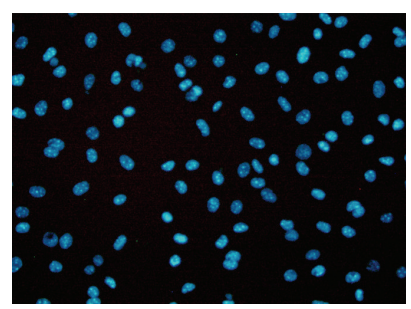

(e)

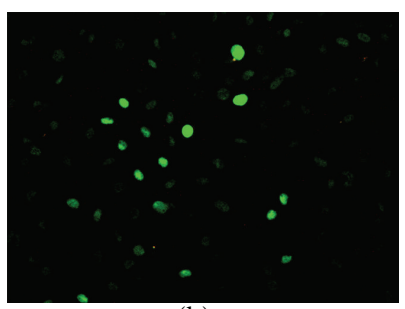

(b)

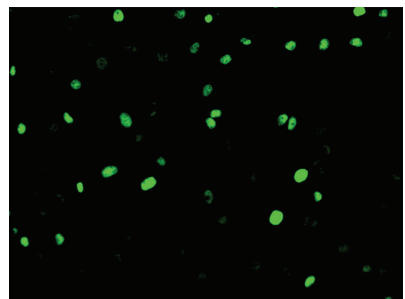

(d)

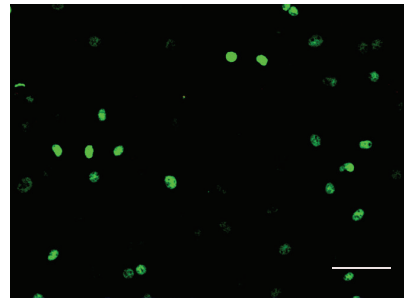

(f)

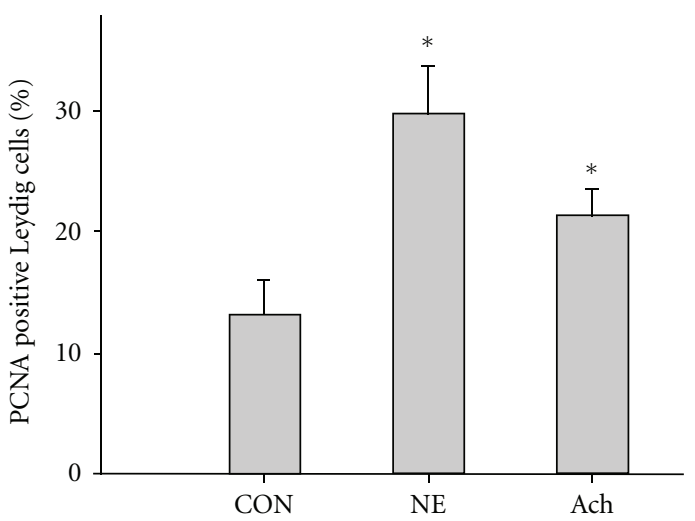

FIgURE 4: Immunofluorescence staining of PCNA in the Leydig cells cultured with NE and Ach on PD15. The percentage of PCNA-positive (green) cells to total Leydig cells (blue) was presented as means \pm SEM. A single asterisks $(*)$ indicates statistical significance $(P<0.05)$ relative to the untreated control. (a) and (b) control group cultured with the same dilution of NE and Ach. (c) and (d) NE group cultured in the presence of $10 \mu \mathrm{M}$ NE. (e) and (f) Ach group cultured in the presence of $10 \mu \mathrm{M}$ Ach. (b, $d$ and f) Originated from the same photo (a), (c) and (e) with FITC staining only. Nuclei (blue) of all Leydig cells were stained with Hoechst 33258. Bar $=50 \mu \mathrm{m}$.

of Leydig cells in PD15 mice which were exposed to different doses of NE and Ach were observed. The results in Figure 2 suggested that $\mathrm{NE}$ at $0.1 \mu \mathrm{M}, 1 \mu \mathrm{M}$, and $10 \mu \mathrm{M}$ significantly stimulated the growth of Leydig cells, compared with the control group $(P<0.05)$. Furthermore, Ach at $1 \mu \mathrm{M}$ and $10 \mu \mathrm{M}$ significantly improved the viability of Leydig cells $(P<0.05)$. Both NE and Ach with a dose of $100 \mu \mathrm{M}$ did not stimulate the viability of Leydig cells.

3.3. Effects of NE and Ach on the Expression of $3 \beta-H S D$ of Leydig Cells in PD 15 Mice. The stem Leydig cells expressed no steroidogenic enzyme. They differentiate into progenitors, and $3 \beta$-HSD expresses between PD 10 and 13 [18]. The results showed that NE and Ach significantly stimulated the expression of $3 \beta-\mathrm{HSD}$, compared with the control group, in the cultured Leydig cells in PD 15 mice (Figure 3$)(P<0.05)$. Therefore, it may be seen that NE and Ach are capable of regulating the differentiation of Leydig cells at prepuberty.

3.4. Effects of NE and Ach on the Expression of PCNA in Cultured Leydig Cells in PD 15 Mice. In order to test the effects of NE and Ach on the proliferation of Leydig cells, PCNA 

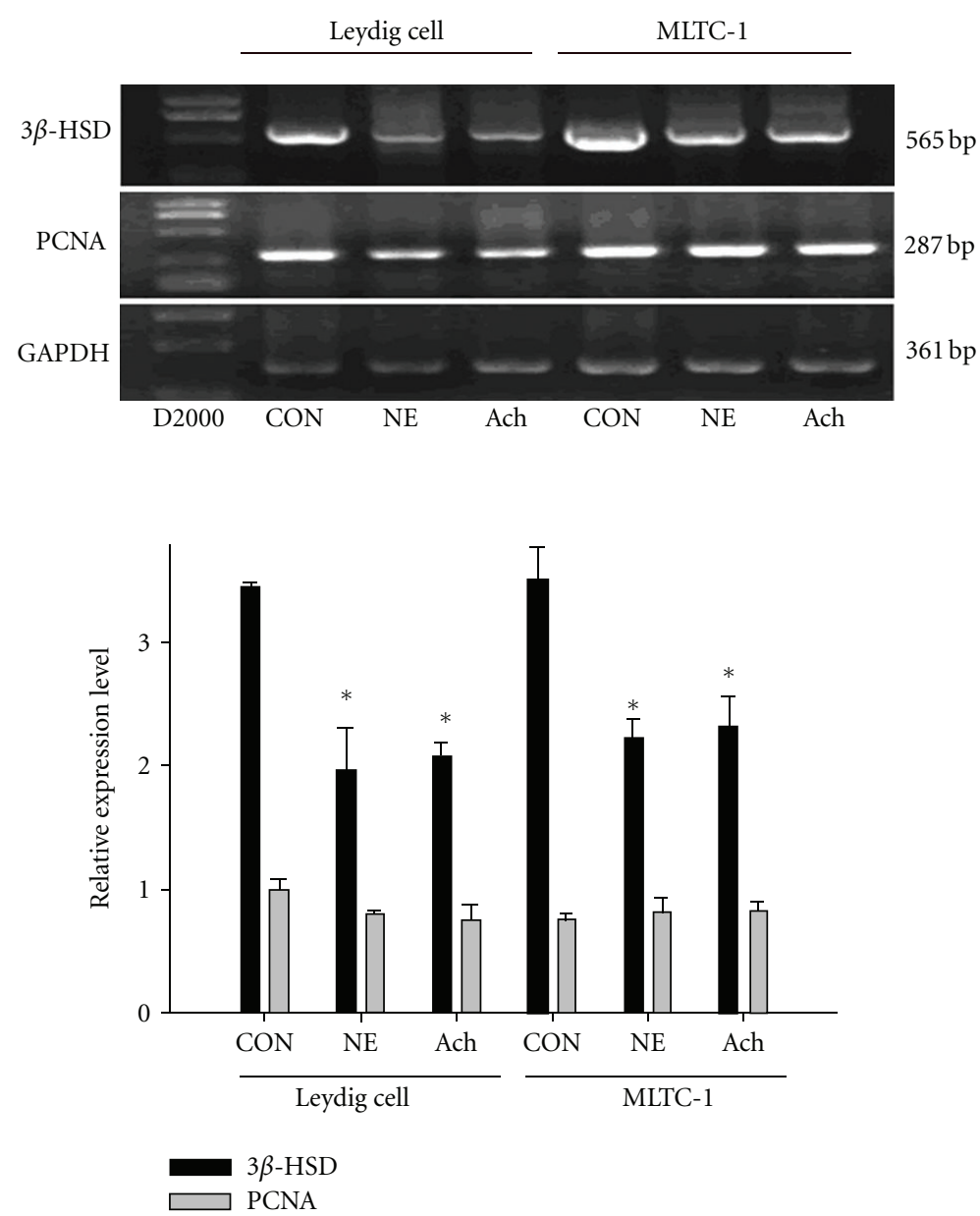

FIgure 5: Expression levels of 3 $\beta$-HSD mRNA and PCNA mRNA in the cultured adult Leydig cells and MLTC-1 treated with NE, and Ach. Asterisks $(*)$ indicate statistical significance $(P<0.05)$ between the CON, NE and Ach groups. CON: Control group cultured with the same dilution of NE and Ach. NE: NE group cultured in the presence of $10 \mu \mathrm{M}$ NE. Ach: Ach group cultured in the presence of $10 \mu \mathrm{M}$ Ach.

immunofluorescence and cell counting were performed. PCNA-labeled cells were identified via nuclear green staining. NE and Ach significantly increased the number of PCNA-positive Leydig cells in PD 15 mice, compared with the control group $(P<0.05)$ (Figure 4$)$. The results indicated that NE and Ach had a great impact on the proliferation of Leydig cells at prepuberty, at which time the population of adult Leydig cells was established.

3.5. Effects of NE and Ach on the Expression of $3 \beta-H S D$ and PCNA mRNA in Adult Leydig Cells and MLTC-1. The RTPCR results (Figure 5) demonstrated that NE and Ach significantly inhibited the expression of $3 \beta$-HSD mRNA in adult mouse Leydig cells and MLTC-1 $(P<0.05)$, but clear effects on the expression of PCNA mRNA were not detected $(P>$ $0.05)$. These results indicated that NE and Ach influenced the expression of $3 \beta$-HSD mRNA, which was involved in testosterone endocrine of adult Leydig cells, but had no effect on the population of adult Leydig cells.

\section{Discussion}

In this study, the roles of NE and Ach involving the proliferation and differentiation of Leydig cells were investigated in vitro. The process by which NE and Ach regulated the development of Leydig cells by means of adrenergic receptors and muscarinic acetylcholine receptors was investigated. Firstly, the expression of adrenergic receptors and muscarinic acetylcholine receptors in Leydig cells was analyzed. It was found that only $\beta 1 \mathrm{AR}, \beta 2 \mathrm{AR}, \alpha 1 \mathrm{D}, \mathrm{M} 1$, and $\mathrm{M} 3$ receptors mRNA was expressed in adult Leydig cells, and in this way, NE and Ach regulated the function of Leydig cells. The mechanisms of the receptors modulating the development and functions of Leydig cells are a topic which still requires further study.

In order to obtain precursor cells, Leydig cells were isolated from PD 15 mice when the cell proliferation and differentiation occurred and developed to the adult population of Leydig cells $[2,3]$. Different doses of NE and Ach $(0.1 \mu \mathrm{M}-100 \mu \mathrm{M})$ were added into the cultures in vitro. The results indicated that the viability of Leydig cells was significantly increased by NE and Ach with doses of 1 and $10 \mu \mathrm{M}$. 
Low or high exposure doses of NE or Ach did not stimulate the viability of the Leydig cells. The reason for this may be the fact that the low doses did not reach the concentration, while the high doses resulted in toxicity of the Leydig cells.

The adult Leydig cells of mice first emerge on PD 10, and the immature Leydig cells undergo proliferation and differentiation on PD 15. By the end of puberty, the development of Leydig cells is completed and the population of adult Leydig cells reaches $25 \times 10^{5}$ per testis [19]. In addition to LH [3], NE, and Ach also regulate the development of Leydig cells, as validated in the above results.

The $3 \beta$-HSD was used as a differentiation indicator of precursor cells [20]. Therefore, the expression of $3 \beta-\mathrm{HSD}$ was detected in the cultured Leydig cells of mouse testis treated with NE and Ach on PD 15. The results showed that $\mathrm{NE}$ and Ach promoted the expression of $3 \beta$-HSD in the cultured Leydig cells. Consequently, NE and Ach were shown to play an important role in the process of the stem Leydig cells differentiating into $3 \beta$-HSD- positive precursor cells.

The proliferation of Leydig cells based on PCNA expression, an indicator of proliferative activity $[21,22]$, was analyzed. The data showed that NE and Ach were able to facilitate the proliferation of cultured Leydig cells on PD 15. As a result, NE and Ach influenced the establishment of the population of adult Leydig cells at prepuberty. It is probable that NE and Ach stimulated the development of Leydig cells through their receptors $\beta 1 \mathrm{AR}, \beta 2 \mathrm{AR}, \alpha 1 \mathrm{D}, \mathrm{M} 1$, and $\mathrm{M} 3$ which were expressed in mouse Leydig cells.

In order to clarify whether NE and Ach had the same effects on adult Leydig cells, the expression of $3 \beta$-HSD and PCNA mRNA in adult leydig cells and MLTC-1 treated with $\mathrm{NE}$ and Ach was detected. It is worth noting that NE and Ach inhibited the expression of $3 \beta$-HSD mRNA and had no effects on the expression of PCNA mRNA in adult Leydig cells and MLTC-1. It may be presumed that the reduction of $3 \beta$-HSD mRNA was related to the testosterone endocrine of the adult Leydig cells. NE and Ach had no effect on the proliferation of the adult Leydig cells. The reason for this may be the fact that the development of adult Leydig cells had been completed at puberty [3].

\section{Conclusions}

It was shown that NE and Ach participated in stimulating the differentiation and proliferation of Leydig cells from prepuberty to the adult stage. NE and Ach had no effect on the population of the adult Leydig cells by the end of puberty, however, they influenced the testosterone endocrine of the Leydig cells by reducing the expression of $3 \beta$-HSD mRNA.

\section{Acknowledgments}

This study was supported by the State Key Laboratory of Agrobiotechnology, College of Biological Sciences, China Agricultural University and the Ministry of Science and Technology of China (no. 2011BAD34B02).

\section{References}

[1] S. M. L. C. Mendis-Handagama, P. A. Watkins, S. J. Gelber, and T. J. Scallen, "The effect of chronic luteinizing hormone treatment on adult rat Leydig cells," Tissue and Cell, vol. 30, no. 1, pp. 64-73, 1998.

[2] M. P. Hardy, B. R. Zirkin, and L. L. Ewing, "Kinetic studies on the development of the adult population of Leydig cells in testes of the pubertal rat," Endocrinology, vol. 124, no. 2, pp. 762-770, 1989.

[3] K. J. Teerds, E. Rijntjes, M. B. Veldhuizen-Tsoerkan, F. F. G. Rommerts, and M. de Boer-Brouwer, "The development of rat Leydig cell progenitors in vitro: how essential is luteinising hormone?" Journal of Endocrinology, vol. 194, no. 3, pp. 579593, 2007.

[4] T. Nagatomo and K. Koike, "Recent advances in structure, binding sites with ligands and pharmacological function of $\beta$ adrenoceptors obtained by molecular biology and molecular modeling," Life Sciences, vol. 66, no. 25, pp. 2419-2426, 2000.

[5] S. K. McCune, M. M. Voigt, and J. M. Hill, "Expression of multiple alpha adrenergic receptor subtype messenger RNAs in the adult rat brain," Neuroscience, vol. 57, no. 1, pp. 143$151,1993$.

[6] R. A. F. Dixon, B. K. Kobilka, and D. J. Strader, "Cloning of the gene and cDNA for mammalian $\beta$-adrenergic receptor and homology with rhodopsin," Nature, vol. 321, no. 6065, pp. 7579, 1986.

[7] R. M. Eglen, A. Choppin, M. P. Dillon, and S. Hegde, "Muscarinic receptor ligands and their therapeutic potential," Current Opinion in Chemical Biology, vol. 3, no. 4, pp. 426-432, 1999.

[8] A. Mayerhofer, R. W. Steger, G. Gow, and A. Bartke, "Catecholamines stimulate testicular testosterone release of the immature golden hamster via interaction with alpha- and betaadrenergic receptors," Acta Endocrinologica, vol. 127, no. 6, pp. 526-530, 1992.

[9] A. L. Favaretto, M. M. Valença, D. L. Picanço-Diniz, and J. A. Antunes-Rodrigues, "Inhibitory role of cholinergic agonists on testosterone secretion by purified rat Leydig cells," Archives Internationales de Physiologie, de Biochimie et de Biophysique, vol. 101, no. 6, pp. 333-335, 1993.

[10] T. F. G. Lucas, M. C. W. Avellar, and C. S. Porto, "Effects of carbachol on rat Sertoli cell proliferation and muscarinic acetylcholine receptors regulation: an in vitro study," Life Sciences, vol. 75, no. 14, pp. 1761-1773, 2004.

[11] E. Chernogubova, D. S. Hutchinson, J. Nedergaard, and T. Bengtsson, " $\alpha 1$ - and $\beta 1$-adrenoceptor signaling fully compensates for $\beta 3$-adrenoceptor deficiency in brown adipocyte norepinephrine-stimulated glucose uptake," Endocrinology, vol. 146, no. 5, pp. 2271-2284, 2005.

[12] J. C. Zimring, L. M. Kapp, M. Yamada, J. Wess, and J. A. Kapp, "Regulation of $\mathrm{CD}^{8+}$ cytolytic T lymphocyte differentiation by a cholinergic pathway," Journal of Neuroimmunology, vol. 164, no. 1-2, pp. 66-75, 2005.

[13] B. T. Akingbemi, R. Ge, C. S. Rosenfeld et al., "Estrogen receptor- $\alpha$ gene deficiency enhances androgen biosynthesis in the mouse Leydig cell," Endocrinology, vol. 144, no. 1, pp. 8493, 2003.

[14] R. Fu, J. Liu, J. Fan et al., "Novel evidence that testosterone promotes cell proliferation and differentiation via $\mathrm{G}$ proteincoupled receptors in the rat L6 skeletal muscle myoblast cell line," Journal of Cellular Physiology, vol. 227, no. 1, pp. 98-107, 2012. 
[15] T. Uehara, M. Kaneko, S. Tanaka, Y. Okuma, and Y. Nomura, "Possible involvement of p38 MAP kinase in HSP70 expression induced by hypoxia in rat primary astrocytes," Brain Research, vol. 823, no. 1-2, pp. 226-230, 1999.

[16] L. Zhang and S. Cui, "Effects of daidzein on testosterone synthesis and secretion in cultured mouse leydig cells," AsianAustralasian Journal of Animal Sciences, vol. 22, no. 5, pp. 618625, 2009.

[17] G. Wang, D. Chen, H. Luo et al., "Low-dose ethanol suppresses $17 \beta$-estradiol activity in GH4C1 pituitary tumor cells," Cell Biology and Toxicology, vol. 26, no. 3, pp. 265-277, 2010.

[18] H. B. S. Ariyaratne, S. M. L. C. Mendis-Handagama, D. B. Hales, and J. I. Mason, "Studies on the onset of Leydig precursor cell differentiation in the prepubertal rat testis," Biology of Reproduction, vol. 63, no. 1, pp. 165-171, 2000.

[19] J. M. Saez, "Leydig cells: endocrine, paracrine, and autocrine regulation," Endocrine Reviews, vol. 15, no. 5, pp. 574-626, 1994.

[20] R. S. Ge, Q. Dong, C. M. Sottas, V. Papadopoulos, B. R. Zirkin, and M. P. Hardy, "In search of rat stem Leydig cells: identification, isolation, and lineage-specific development," Proceedings of the National Academy of Sciences of the United States of America, vol. 103, no. 8, pp. 2719-2724, 2006.

[21] P. O. Koh and M. O. Kim, "Ethanol exposure decreases cell proliferation and increases apoptosis in rat testes," Journal of Veterinary Medical Science, vol. 68, no. 10, pp. 1013-1017, 2006.

[22] S. M. Ruwanpura, R. I. McLachlan, K. L. Matthiesson, and S. J. Meachem, "Gonadotrophins regulate germ cell survival, not proliferation, in normal adult men," Human Reproduction, vol. 23, no. 2, pp. 403-411, 2008. 


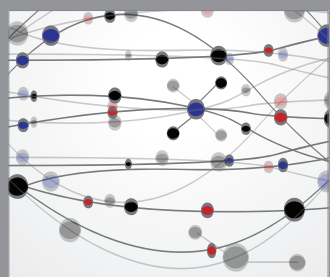

The Scientific World Journal
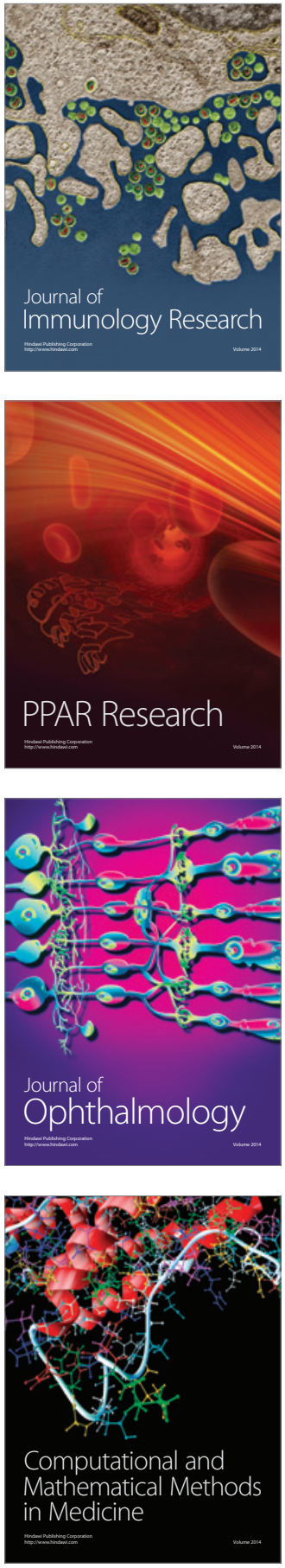

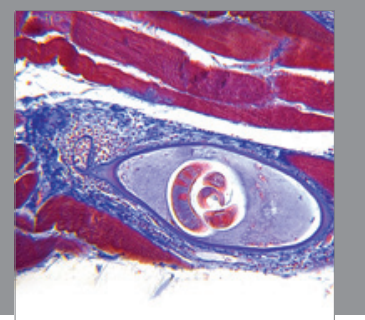

Gastroenterology

Research and Practice
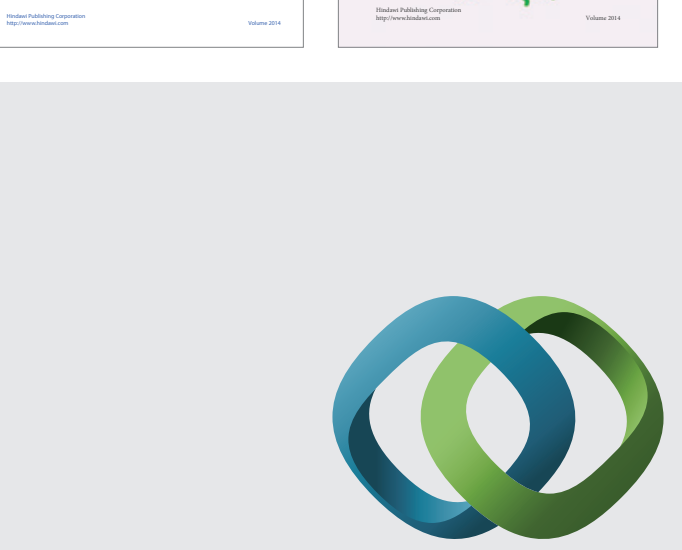

\section{Hindawi}

Submit your manuscripts at

http://www.hindawi.com
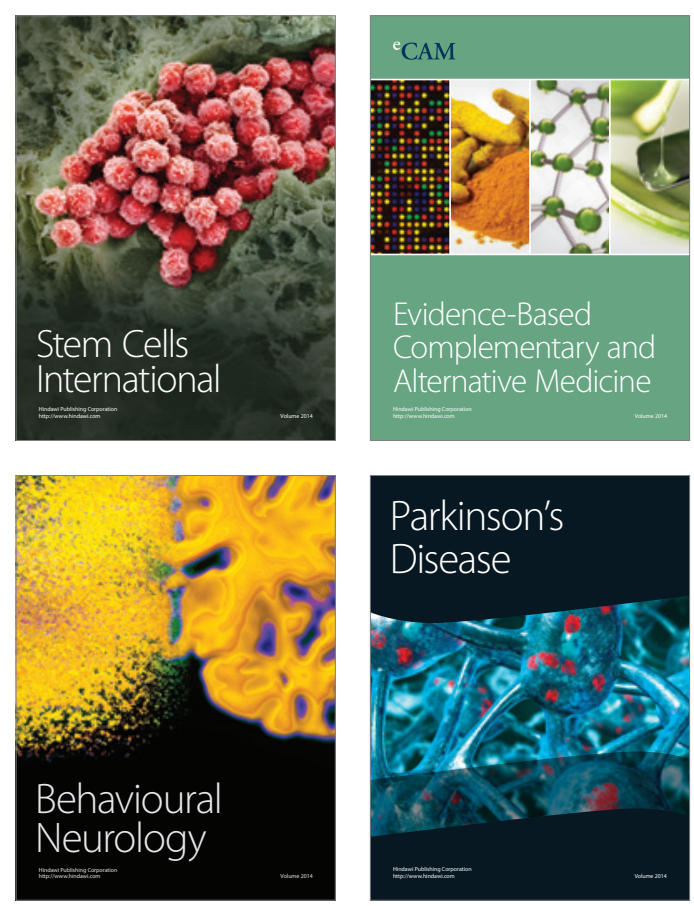

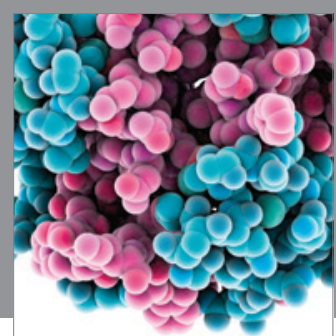

Journal of
Diabetes Research

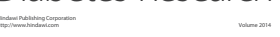

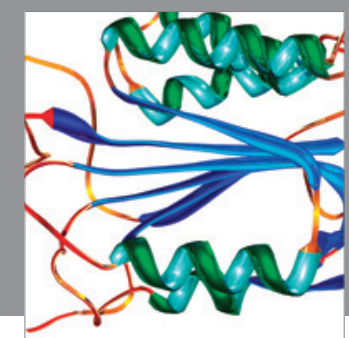

Disease Markers
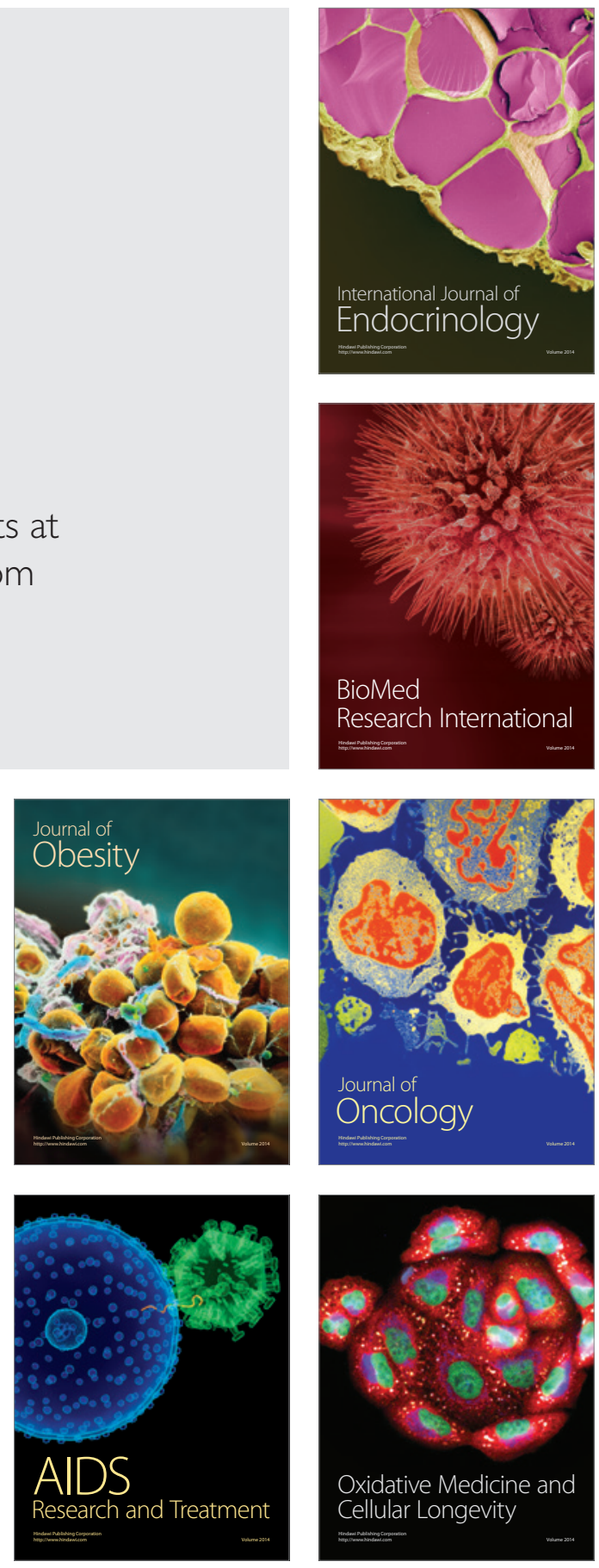